\title{
Clinical Remission of Chronic Spontaneous Urticaria (CSU): A Targeted Literature Review
}

\author{
Maria-Magdalena Balp • Anna C. Halliday • Thomas Severin • \\ Saoirse A. Leonard - Gautam Partha · Manik Kalra · Alexander M. Marsland
}

Received: September 28, 2021 / Published online: November 22, 2021

(C) The Author(s) 2021

\section{ABSTRACT}

Introduction: Chronic spontaneous (previously known as idiopathic) urticaria (CSU) is a chronic skin disease with the potential for natural remission. The objectives of this targeted literature review were to identify evidence on the clinical course of CSU, including remission rates, and to estimate cumulative remission rates for different time points.

Methods: Electronic databases (MEDLINE, MEDLINE-In Process, Embase, Web of Science, BIOSIS Previews and the Cochrane Library) and relevant conference proceedings were searched

Supplementary Information The online version contains supplementary material available at https:// doi.org/10.1007/s13555-021-00641-6.

M.-M. Balp · T. Severin

Novartis Pharma AG, Basel, Switzerland

A. C. Halliday

Health Economics and Outcomes Research, Novartis

Pharmaceuticals UK Limited, London, UK

S. A. Leonard

Costello Medical Ltd, Cambridge, UK

G. Partha · M. Kalra $(\square)$

Novartis Healthcare Pvt. Ltd., Hyderabad, India

e-mail: manik.kalra@novartis.com

A. M. Marsland

Department of Dermatology \& University of

Manchester, Salford Royal Foundation Trust,

Manchester, UK to identify studies involving patients with CSU aged $\geq 12$ years that provide data on remission rates and disease duration. Observational studies with patient follow-ups of $\geq 1$ year or review articles were included. Data extracted from five selected studies were used to run Kaplan-Meier (KM) analyses and best-fit distributions to calculate remission rates per 4-week period and weighted averages.

Results: Ten publications were included in this review. The proportion of patients achieving remission within year 1 ranged from 21 to $47 \%$, while reported remission rate estimates at year 5 were $34 \%$ and $45 \%$. Based on calculated 4-weekly remission rates, cumulative remission estimates ranged from 9 to $38 \%$ at year 1, from 29 to $71 \%$ at year 5 and from 52 to $93 \%$ at year 20. Cumulative weighted average estimates for the proportion of patients remitting at years 1, 5 and 20 were $17 \%, 45 \%$ and $73 \%$, respectively.

Conclusions: Published evidence suggests that CSU is a self-limiting condition with variable disease severity and duration, apparently dependent on multiple factors. However, data sources differed in terms of definitions of disease severity and remission, as well as in conclusions on influencing factors. Further studies and uniform definitions are required.

Keywords: Chronic spontaneous urticaria; Duration of disease; Natural clinical remission; Remission rate 


\section{Key Summary Points}

Chronic spontaneous/idiopathic urticaria (CSU/CIU) is a debilitating skin condition characterized by the development of hives with or without angioedema, persisting for longer than 6 weeks and with no identifiable trigger.

Existing evidence revealed the inconsistency in the definitions of spontaneous remission in CSU.

To better understand the clinical course of $\mathrm{CSU}$, it is necessary to come to a consensus on the definitions of disease severity and remission rates.

\section{INTRODUCTION}

Chronic spontaneous urticaria (CSU), previously known as chronic idiopathic urticaria (CIU), is a skin condition defined as the occurrence of wheals/hives, angioedema or both, for $\geq 6$ weeks without a specific identifiable trigger [1]. Symptoms of CSU are very distressing and have a major impact on health-related quality of life (HRQoL), with patients experiencing itch and discomfort, loss of energy, sleep disturbance, emotional distress and restrictions to their social and work life $[2,3]$. The most recent international EAACI/GA ${ }^{2} \mathrm{LEN} / \mathrm{EDF} / \mathrm{WAO}$ consensus guidelines for CSU treatment recommend a stepwise approach, starting with licensed doses of second-generation $\mathrm{H}_{1}$ - antihistamines as the first-line treatment, and increasing to up to fourfold the licensed dose if control is inadequate [4]. Omalizumab is added as third-line treatment to patients who do not respond to first- and second-line treatments according to the guidelines [4]. These treatments can result in symptom control and improved HRQoL in many patients, but are unlikely to alter the duration of the disease.

The average disease duration in CSU has been estimated to be 5 years, although it may persist longer in severe cases [5]. Patients' symptoms can spontaneously resolve over time, and remission may occur independently of treatment [6]. Rates of spontaneous remission are of great interest to both clinicians and patients as they can support decisions on actual duration of treatment. Although a few studies have evaluated spontaneous remission rates in CSU [7-9], up to now, a qualitative and quantitative assessment on remission rates and factors influencing them has not been published.

The primary objective of this study was to perform a targeted literature review to identify studies that assessed the course of CSU with a focus on the following: definitions of remission, remission rates, duration of short-term remission, duration of disease and relapse rates following remission. A secondary objective was to fit the literature-based remission rates into a statistical model to extrapolate the data and estimate cumulative remission rates for different time points.

\section{METHODS}

This targeted literature review was based on a comprehensive search of evidence from previously conducted studies and does not contain any new studies with human participants or animals performed by any of the authors. Studies were included based on predefined eligibility criteria.

\section{Databases Searched}

MEDLINE, MEDLINE-In Process, Embase, Web of Science, BIOSIS Previews and the Cochrane Library were searched from database inception up to May 2021. Search terms for CSU/CIU were combined with terms for study design or outcomes of interest. In addition to medical databases, abstracts from selected congress (Annual Meeting of the European Society for Dermatological Research, American Academy of Dermatology, American Academy of Allergy, Asthma and Immunology, American College of Allergy, Asthma and Immunology, British Association of Dermatologists, European Academy of Allergy and Clinical Immunology, European Academy 
of Dermatology and Venerology, German Dermatology Society, and World Allergy Organization) proceedings were screened, and reference lists of included articles were hand-searched (Electronic Supplementary Material [ESM] Table 1).

\section{Eligibility Criteria}

The eligibility criteria included observational studies on CSU patients (aged $\geq 12$ years) with a follow-up of $\geq 1$ year that reported definitions of remission (the absence of disease symptoms in the absence of treatment), remission rates, duration of remission, duration of disease (i.e. from first symptoms/diagnosis until remission) and relapse rates following remission (reappearance of symptoms such as itchy hives and/ or angioedema following a remission period). Published literature reviews reporting these outcomes were also included (ESM Table 2).

Case studies/reports and citations considering only children $(<12$ years old) or other urticaria subtypes were excluded. Citations were screened by two independent reviewers, and any discrepancies between reviewers were resolved by a third independent reviewer.

\section{Data Extraction and Analysis}

Data from the studies meeting the eligibility criteria were extracted by a single reviewer and verified by a second reviewer. After extraction, the data were used to generate estimated CSU remission rate curves over a lifetime period. For studies that did not report the numerical proportion of patients achieving remission at each time point $[9,10]$, data were extracted from the presented graphs. Specifically for one study [9], the graphs were presented separately for hypertensive and normotensive patients, which were then pooled together to determine remission rates for the overall population. Several statistical distributions (exponential, log-normal, Weibull and log-logistic) were tested to identify the distribution best fitting the literature estimates. The lowest Kolmogorov-Smirnov (KS) distance was chosen as the criterion for the best fit distribution (ESM
Table 3). For the chosen distribution for each study, the probability of individuals not undergoing remission was derived using a Kaplan-Meier (KM) analysis. The best-fit distribution was then used to extract 4-weekly remission rates. Values obtained from the bestfit distribution were further converted into rates appropriate for 4-week model cycles. Although direct comparisons across studies were challenging due to differences in study design, disease severity of the studied cohorts and varying definitions of remission, a simplifying assumption of homogeneity across studies was applied to synthesize the available evidence and generate single-point estimates at various time points, based on a sample size weighted average of the remission estimates in each individual analysis. All analyses were conducted using $\mathrm{R}$ for Windows, and KM curves were read using Enguage software.

\section{RESULTS}

\section{Qualitative Results}

After applying inclusion and exclusion criteria to titles and abstracts, we identified 53 potentially relevant articles for full-text screening. Of these, eight observational studies [7-14] and two review articles [6, 15] were ultimately included in the review. One of the review articles was a systematic review [15] which provided an overview of urticaria, including the clinical remission of chronic urticaria (CU) and remission rates (ESM Fig. 1).

\section{Summary of Studies}

A summary of the studies' characteristics is presented in Table 1 . The studies were published between 2001 and 2018. Four were prospective observational studies (collecting patient data from allergy clinics and/or secondary/tertiary care centers) $[7,9,11,14]$, and four were retrospective observational studies (data were extracted from medical chart reviews, tertiary care centers and claims databases) $[8,10,12,13]$. The studies were conducted in the Netherlands [7, 10], Israel [14], Italy [9], Thailand $[8,11,12]$ and Korea [13]. Sample sizes 
Table 1 Overview of observational studies identified in the review

\begin{tabular}{|c|c|c|c|c|c|c|}
\hline Study ${ }^{a}$ & Study design & Data source & $\begin{array}{l}\text { Sample } \\
\text { size }(\mathbf{N})\end{array}$ & $\begin{array}{l}\text { Patient } \\
\text { demographics }\end{array}$ & Comorbidities & $\begin{array}{l}\text { Definition of } \\
\text { outcomes } \\
\text { measured }\end{array}$ \\
\hline $\begin{array}{l}\text { Koze, } 2001[7] \text {; } \\
\text { the } \\
\text { Netherlands }\end{array}$ & $\begin{array}{l}\text { Prospective } \\
\text { cohort study } \\
\text { with follow- } \\
\text { up of at least } \\
1 \text { year }\end{array}$ & $\begin{array}{l}\text { Single } \\
\text { outpatient } \\
\text { secondary } \\
\text { and tertiary } \\
\text { care center } \\
\text { between } 1992 \\
\text { and } 1994\end{array}$ & $\begin{array}{l}\text { Total } \\
\text { sample: } \\
220 \\
\text { CIU }^{\mathrm{b}} \\
\text { patients: } \\
78\end{array}$ & $\begin{array}{l}\text { Not reported } \\
\text { for the CIU } \\
\text { patients }\end{array}$ & Not reported & $\begin{array}{l}\text { Remission: } \\
\text { proportion of } \\
\text { patients free } \\
\text { of symptoms } \\
\text { after } 1 \text { year }\end{array}$ \\
\hline $\begin{array}{l}\text { Van Der Valk, } \\
2002 \text { [10]; the } \\
\text { Netherlands }\end{array}$ & $\begin{array}{l}\text { Retrospective } \\
\text { cohort study }\end{array}$ & $\begin{array}{l}\text { Tertiary referral } \\
\text { center at a } \\
\text { university } \\
\text { hospital } \\
\text { between } 1968 \\
\text { and } 1990\end{array}$ & $\begin{array}{l}\text { Total } \\
\text { sample: } \\
372 \\
\text { CIU }^{\mathrm{b}} \\
\text { patients: } \\
153\end{array}$ & $\begin{array}{l}\text { Mean age: } \\
36 \text { years } \\
\text { Female: } 62 \%\end{array}$ & Not reported & $\begin{array}{l}\text { Remission: } \\
\text { proportion of } \\
\text { patients free } \\
\text { of symptoms } \\
\text { after } 5 \text { and } \\
10 \text { years }\end{array}$ \\
\hline $\begin{array}{l}\text { Toubi, } 2004 \\
\text { [14]; Israel }\end{array}$ & $\begin{array}{l}\text { Prospective } \\
\text { study with a } \\
\text { follow-up of } \\
5 \text { years }\end{array}$ & $\begin{array}{l}\text { Outpatient } \\
\text { allergy clinics } \\
\text { from } 1998 \\
\text { until } 2003\end{array}$ & $\begin{array}{c}\mathrm{CIU}^{\mathrm{b}}: 145 \\
\text { patients }\end{array}$ & $\begin{array}{l}\text { Mean age: } \\
\quad 41 \text { years } \\
\text { Female: } 63 \%\end{array}$ & Not reported & $\begin{array}{l}\text { Duration of } \\
\text { disease: } \\
\text { presence of } \\
\text { symptoms } \\
\text { during } \\
\text { 60-month } \\
\text { follow-up } \\
\text { Factors } \\
\text { influencing } \\
\text { the disease } \\
\text { duration }\end{array}$ \\
\hline $\begin{array}{c}\text { Kulthanan, } 2007 \\
\text { [8]; Thailand }\end{array}$ & $\begin{array}{l}\text { Retrospective } \\
\text { study with } \\
\text { follow-up of } \\
\text { at least } 1 \text { year }\end{array}$ & $\begin{array}{l}\text { Medical } \\
\text { chart review }\end{array}$ & $\begin{array}{l}\text { Total } \\
\text { sample: } \\
450 \\
\text { CIU }^{\mathrm{b}} \\
\text { patients: } \\
337\end{array}$ & $\begin{array}{l}\text { Mean age: } \\
34 \text { years } \\
\text { Female: } 80 \%\end{array}$ & Not reported & $\begin{array}{l}\text { Remission: } \\
\text { proportion of } \\
\text { patients free } \\
\text { of symptoms } \\
\text { after } 1 \text { year }\end{array}$ \\
\hline
\end{tabular}


Table 1 continued

\begin{tabular}{|c|c|c|c|c|c|c|}
\hline Study ${ }^{a}$ & Study design & Data source & $\begin{array}{l}\text { Sample } \\
\text { size }(\mathrm{N})\end{array}$ & $\begin{array}{l}\text { Patient } \\
\text { demographics }\end{array}$ & Comorbidities & $\begin{array}{l}\text { Definition of } \\
\text { outcomes } \\
\text { measured }\end{array}$ \\
\hline $\begin{array}{c}\text { Nebiolo, } 2009 \\
\text { [9]; Italy }\end{array}$ & $\begin{array}{l}\text { Prospective } \\
\text { cohort study } \\
\text { with a follow- } \\
\text { up of up to } \\
5 \text { years }\end{array}$ & $\begin{array}{l}\text { Two outpatient } \\
\text { allergy clinics } \\
\text { from January } \\
2003 \text { to } \\
\text { December } \\
2005\end{array}$ & $\begin{array}{l}\mathrm{CIU}^{\mathrm{b}} \\
\text { patients: } \\
228\end{array}$ & $\begin{array}{l}\text { Mean age: } \\
48.2 \text { years } \\
\text { Female: } 73 \%\end{array}$ & $\begin{array}{l}\text { Atopy: } 40 \% \\
\text { Allergic diseases } \\
\text { (rhinitis and } \\
\text { asthma): } 29 \% \\
\text { Arterial } \\
\text { hypertension: } \\
18 \% \\
\text { H. pylori } \\
\text { infection: } 32 \%\end{array}$ & $\begin{array}{l}\text { Remission: } \\
\text { absence of } \\
\text { hives and } \\
\text { angioedema } \\
\text { in the last } 3 \\
\text { months } \\
\text { without } \\
\text { therapy } \\
\text { Duration of } \\
\text { disease: } \\
\text { presence of } \\
\text { symptoms } \\
\text { during } \\
\text { 60-month } \\
\text { follow-up } \\
\text { Factors } \\
\text { influencing } \\
\text { the disease } \\
\text { duration }\end{array}$ \\
\hline $\begin{array}{l}\text { Boonpiyathad, } \\
2016 \text { [11]; } \\
\text { Thailand }\end{array}$ & $\begin{array}{l}\text { Prospective } \\
\text { observational } \\
\text { study }\end{array}$ & $\begin{array}{l}\text { Allergy Clinic } \\
\text { Hospital, } \\
\text { Bangkok, } \\
\text { Thailand } \\
\text { from } 2012 \text { to } \\
2015\end{array}$ & $\begin{array}{l}\text { CSU } \\
\text { patients: } \\
128\end{array}$ & $\begin{array}{l}\text { Mean age: } \\
35 \text { years } \\
\text { Female: } 66 \%\end{array}$ & $\begin{array}{l}\text { Allergic rhinitis: } \\
\quad 6 \%\end{array}$ & $\begin{array}{l}\text { Remission: no } \\
\text { symptoms for } \\
\text { at least } 4 \\
\text { weeks } \\
\text { without } \\
\text { medication, } \\
\text { and } \\
\text { calculated at } \\
2 \text { years }\end{array}$ \\
\hline
\end{tabular}


Table 1 continued

\begin{tabular}{|c|c|c|c|c|c|c|}
\hline Study ${ }^{a}$ & Study design & Data source & $\begin{array}{l}\text { Sample } \\
\text { size }(N)\end{array}$ & $\begin{array}{l}\text { Patient } \\
\text { demographics }\end{array}$ & Comorbidities & $\begin{array}{l}\text { Definition of } \\
\text { outcomes } \\
\text { measured }\end{array}$ \\
\hline $\begin{array}{l}\text { Chuamanochan, } \\
2016 \text { [12]; } \\
\text { Thailand }\end{array}$ & $\begin{array}{l}\text { Retrospective } \\
\text { study }\end{array}$ & $\begin{array}{l}\text { Department of } \\
\text { Dermatology } \\
\text { between the } \\
\text { years } \\
2000-2013\end{array}$ & $\begin{array}{l}\text { CSU } \\
\text { patients: } \\
201\end{array}$ & $\begin{array}{l}\text { Older patients: } \\
\text { Mean age: } \\
67 \text { years } \\
\text { Female: } 67 \% \\
\text { Younger } \\
\text { patients: } \\
\text { Mean age: } \\
36 \text { years } \\
\text { Female: } 78 \%\end{array}$ & $\begin{array}{l}\text { Older vs. } \\
\text { younger } \\
\text { patients } \\
\text { Allergic rhinitis: } \\
22 \% \text { vs } 19 \% \\
\text { Asthma: } 2 \% \text { vs } \\
5 \% \\
\text { Atopic } \\
\text { dermatitis: } 0 \% \\
\text { vs } 2 \% \\
\text { Allergic } \\
\text { conjunctivitis: } \\
0 \% \text { vs } 1 \%\end{array}$ & $\begin{array}{l}\text { Remission: } \\
\text { patients free } \\
\text { of symptoms } \\
\text { after } 1 \text { year }\end{array}$ \\
\hline $\begin{array}{l}\text { Kim, } 2018 \text { [13]; } \\
\text { Korea }\end{array}$ & $\begin{array}{l}\text { Design: } \\
\text { nationwide, } \\
\text { population- } \\
\text { based study } \\
\text { with a } \\
\text { median } \\
\text { follow-up of } \\
6.7 \text { years }\end{array}$ & $\begin{array}{l}\text { Korean } \\
\text { National } \\
\text { Health } \\
\text { Insurance } \\
\text { Service } \\
\text { National } \\
\text { Sample } \\
\text { Cohort from } \\
2002 \text { to } 2013\end{array}$ & $\begin{array}{l}\text { CSU } \\
\text { patients: } \\
13,969\end{array}$ & $\begin{array}{l}\text { Age: } \geq 20 \text { years } \\
\text { Female: } 61 \%\end{array}$ & Not reported & $\begin{array}{l}\text { Remission: not } \\
\text { being } \\
\text { diagnosed } \\
\text { with urticaria } \\
\text { for at least } \\
1 \text { year during } \\
\text { follow-up, } \\
\text { reported by } \\
\text { age groups } \\
\text { and } \\
\text { cumulative } \\
\text { rate }\end{array}$ \\
\hline
\end{tabular}

CSU/CIU Chronic spontaneous (idiopathic) urticaria, $C U$ chronic urticaria

${ }^{a}$ First author of study, publication year [reference number] and country

${ }^{\mathrm{b}} \mathrm{CIU}$ is another name used for CSU and was used in the respective study

ranged from 78 [7] to 228 patients [9] in prospective studies and from 153 [10] to 13,969 patients [13] in retrospective studies. Some studies excluded inducible urticaria (i.e. urticaria induced by a known trigger, such as cold, heat, pressure, among others) and others did not.
The definition of the disease was generally based on the guidelines as urticaria lasting at least 6 weeks with no identifiable trigger $[8,9,11,12]$. Certain studies presented details related to the inclusion and exclusion criteria of patients or disease severity levels. Where reported, criteria were based on study-specific 
questionnaires, medical history, clinical examination, laboratory testing or International Classification of Diseases (ICD) codes $[7,10,13,14]$. The majority of studies included patients with and without angioedema [7, 9-12, 14].

Across all studies, the reporting of demographic characteristics for CSU patients was relatively limited. Mean patient age across the observational studies ranged from 34 [8] to 67 years [12]. One study reported results according to different age groups (20-39 years, $40-64$ years and $>65$ years) [13]. The proportion of females ranged from $61 \%$ [13] to $80 \%$ [8]. Not all studies reported treatment details. One study reported treatments for patients with all CU subtypes, without specific details for the 78 patients with CSU [7]. Two studies [9, 14] provided sufficient treatment details to ascertain that at least some CSU patients were receiving antihistamines and oral corticosteroids.

In terms of outcomes measured, the studies reported remission rates at different time points $[7,8,10-13]$, duration of disease $[9,14]$ and factors influencing severity and/or duration of disease $[9,12-14]$. None of the included studies reported relapse rates.

\section{Remission Rates}

In most studies remission was defined as the proportion of CSU patients free of symptoms in the absence of treatment over various periods of time. Remission rates were reported within year 1 in three studies $[7,8,12]$, at years 5 and 10 in one study [10] and at multiple time points (years 1, 2, 3, 4 and 5) in another study [13]. One study defined remission as the absence of urticaria symptoms for at least 4 weeks without medication, and reported remission rate at year 2 [11], and another study defined remission as the absence of hives and angioedema in the last 3 months while patients were not undergoing therapy [9], and reported results at years 2 and 5.

The proportions of patients in remission at different time points, either after symptom onset or after study commencement, were reported in six observational studies and one review article [6], as shown in Table 2. The proportion of patients achieving remission within year 1 ranged from $21 \%$ [12] to $47 \%$ [7] and at year 2 from 33\% [13] to 64\% [11]. Reported remission rates at year 5 were 34\% [10] and $45 \%$ [13], while remission at year 10 was reported as being $49 \%$ [10]. The remission rates reported in the review article [6], reported as the percentage of $\mathrm{CU}$ patients with disease resolution, were $50 \%, 20 \%$ and $20 \%$ within 6 months, 3 years and 5 years from disease onset, respectively; the calculated cumulative remission rate at year 5 was $90 \%$.

\section{Duration of Disease in CSU}

Duration of disease, defined as the presence of disease symptoms during a follow-up of 60 months, was assessed in two studies $[9,14]$. In one of these studies, the persistence of CSU symptoms at the end of $12,24,36$ and 60 months was reported in 75\%, 52\%, 43\% and $14 \%$ of patients, respectively [14]. In the other study, persistence of disease was assessed among hypertensive patients compared to normotensive patients [9]. Among hypertensive patients, CSU persisted up to 24 months in $81 \%$ of patients and up to 60 months in $63 \%$, while in normotensive patients the disease persisted in $74 \%$ and $54 \%$ of patients at 24 and 60 months, respectively [9]. In this latter study, the values for the proportion of patients with CSU at 24 and 60 months reported in the text summary were found to be inconsistent with values in the $\mathrm{KM}$ curves in the figure; hence, the values presented in the KM curves were used in this review [9].

\section{Factors Influencing CSU Duration}

Four studies investigated the factors influencing remission rates in CSU patients [9, 12-14], as shown in Table 3. Although CSU is defined as one clinical phenotype, heterogeneity exists between patients not only in the severity of disease, but also in the response to tests aimed at identifying underlying autoimmunity or autoallergy, and even in the rapidity of response to treatment. Positive autologous serum skin tests (ASST) or autologous plasma skin tests (APST) are indicators of autoimmune aetiology of urticaria; the presence of antinuclear 
Table 2 Proportion of patients in remission at different time points as reported in the included studies

\begin{tabular}{llllllll}
\hline Study $^{\mathbf{a}}$ & $\mathbf{6}$ months & $\mathbf{1}$ year & $\mathbf{2}$ year & $\mathbf{3}$ year & 4 year & $\mathbf{5}$ year & $\mathbf{1 0}$ year \\
\hline Kozel, 2001 [7] & - & $47 \%$ & - & - & - & - & - \\
Beltrani, 2002 [6] & $50 \%$ & - & - & $20 \%$ & - & $20 \%$ & - \\
Van Der Valk, 2002 [10] & - & - & - & - & - & $34 \%$ & $49 \%$ \\
Kulthanan, 2007 [8] & - & $35 \%$ & - & - & - & - & - \\
Boonpiyathad, 2016 [11] & - & - & $64 \%$ & - & - & - & - \\
Chuamanochan, 2016 [12] & - & $21 \%$ & - & - & - & - & - \\
Kim, 2018 [13] & - & $22 \%$ & $33 \%$ & $39 \%$ & $43 \%$ & $45 \%$ & - \\
\hline
\end{tabular}

${ }^{\mathrm{a}}$ First author of study, publication year [reference number]

${ }^{\mathrm{b}}$ Review article does not report cumulative numbers

Table 3 Factors influencing duration of CSU

\begin{tabular}{ll}
\hline Study $^{\mathbf{a}}$ & Factors associated with longer CSU duration \\
\hline Toubi, 2004 [14]; Israel & $\begin{array}{l}\text { Urticaria severity, angioedema, autologous serum or plasma skin tests, presence of } \\
\text { antinuclear antibodies }\end{array}$ \\
Nebiolo, 2009 [9]; Italy & $\begin{array}{l}\text { Presence of systemic hypertension } \\
\text { Kim, 2018 [13]; Korea }\end{array}$ \\
$\begin{array}{l}\text { Patient age }>\text { 65 years } \\
\text { Sex: female patients were more likely to enter remission than male patients }\end{array}$ \\
$\begin{array}{l}\text { Chuamanochan, 2016 [12]; } \\
\text { Thailand }\end{array}$ \\
\hline
\end{tabular}

${ }^{a}$ First author of study, publication year [reference number] and country

antibodies (ANA) and antithyroid antibodies (ATA) provide evidence of autoimmunity. Atopy may be associated with autoallergy, and it is possible that both autoallergic and autoimmune factors occur in the same patient. One study assessed the influence of clinical and laboratory parameters on CSU duration and found that urticaria severity, angioedema, ASST results, APST results and presence of ATA were all significantly associated with extended duration of the disease (all $p$ values $<0.05$ ) [14]. In another study, presence of systemic hypertension was significantly associated with longer duration of CSU (hazard ratio [HR] 0.71; 95\% confidence interval [CI] 0.53-0.95; $p=0.02$ ) [9], but the use of antihypertensive drugs did not have an influence on urticaria duration [9].
Other factors, such as angioedema, positive ASST results, presence of ANA and/or ATA, and atopy were not found to be predictive of urticaria remission (all $p$ values $>0.05$ ) [9]. Significant differences in remission rates were reported between age groups and gender. Patients aged $>65$ years were less likely to enter remission compared with patients aged 20-39 years (odds ratio [OR] 0.86 ; 95\% CI 0.77-0.97; $p=0.040)$, and female patients were more likely to enter remission than male patients (OR 1.15; 95\% CI 1.53-1.25; $p<0.001$ ) [13]. Another study suggested the opposite influence of age: mean disease duration was shorter in the older group ( $>60$ years; mean age 67 years) than in the younger group $(<60$ years; mean age 35.6 years), but the difference $(2.21$ vs 
5.11 years) was not significant [12]. The systematic review assessed the relevance of several parameters as either markers of disease severity or predictors of disease duration in CSU patients [15]. The data were not sufficient to confirm an association of parameters such as angioedema or ASST results with CSU duration or severity, although disease severity might predict CSU duration. Heterogeneity across studies made it difficult to draw any definitive conclusions [15].

\section{Quantitative Results}

Data from four studies $[9,10,13,14]$ and the review article [6] were found suitable to calculate remission rates. Analysis was not possible for the remaining studies due to the limited number of data points that made them inappropriate for curve fitting to predict remission $[7,8,11,12]$. The data points in Table 4 represent the proportion of patients that had not entered remission and were calculated from the reported remission rates. The curve fit using different statistical distributions for all five studies, including population subgroups within two of the studies, are presented in Fig. 1. A summary of cumulative remission rates over years 1, 2, 3, 5, 10 and 20 (based on 4-weekly remission rates estimated from best-fitting curve) is presented in Fig. 2. Cumulative remission estimates ranged from $9 \%$ to $38 \%$ at year 1 , from $29 \%$ to $71 \%$ at year 5 and from $52 \%$ to $93 \%$ at year 20 . Since direct comparisons across studies were challenging, a simplifying assumption of homogeneity was applied to generate weighted average estimates for the cumulative proportion of patients remitting at years 1,5 and 20, which were 17,45 and $73 \%$, respectively (Fig. 2). The review article did not report the sample size of patients and hence was not included in the weighted average [6].

\section{DISCUSSION}

This review reports data published on the clinical remission of CSU focusing on duration of disease, remission rates and factors influencing these. It is based on eight observational studies and two review articles that fulfilled the eligibility criteria. The cumulative proportion of patients undergoing remission within year 1 ranged from $21 \%$ [12] to $47 \%$ [7], while at year 5 , it was reported as 34\% [10] and 45\% [13]. Therefore, while some evidence exists on spontaneous remission rates in CSU, uncertainties remain, which may, at least in part, be due to variability in spontaneous remission definitions as well as type of CSU population considered. One study defined remission as "the absence of hives and angioedema in the last

Table 4 Proportions of patients who had not entered remission at the different time points (months)

\begin{tabular}{llllllllll}
\hline Study $^{\mathbf{a}}$ & Included patients & $\mathbf{6}$ & $\mathbf{1 2}$ & $\mathbf{2 4}$ & $\mathbf{3 6}$ & $\mathbf{4 8}$ & $\mathbf{6 0}$ & $\mathbf{1 2 0}$ & $\mathbf{3 0 0}$ \\
\hline Beltrani, 2002 [6] & Persistent urticaria patients & $50 \%$ & - & - & $30 \%$ & - & $10 \%$ & - & $\leq 8 \%$ \\
$\begin{array}{l}\text { Van der Valk, 2002 } \\
\quad \text { CSU] }\end{array}$ & $\begin{array}{l}\text { CSUatients with or without } \\
\text { angioedema }\end{array}$ & - & - & - & - & - & $66 \%$ & $51 \%$ & - \\
Toubi, 2004 [14] & Mild to severe CSU patients & $94 \%$ & $75 \%$ & $52 \%$ & $43 \%$ & - & $14 \%$ & - & - \\
Nebiolo, 2009 [9] & All patients & - & - & $74 \%$ & - & - & $54 \%$ & - & - \\
Kim, 2018 [13] & All patients & - & $78 \%$ & $67 \%$ & $61 \%$ & $57 \%$ & $55 \%$ & - & - \\
\hline
\end{tabular}

For Toubi et al. [14] and Nebiolo et al. [9], values are presented as reported in citations, while for Beltrani et al. [6], Van der Valk et al. [10] and Kim et al. [13] values were calculated (assuming overall population constituted 100\%, proportion not entering remission were calculated after subtracting the patients who had remitted in the overall population). The studies of Kozel et al. [7], Kulthanan et al. [8], Boonpiyathad et al. [11] and Chuamanochan et al. [12] were not included due to the limited number of data points which made them inappropriate for curve fitting to predict remission

${ }^{a}$ First author of study, publication year [reference number] 

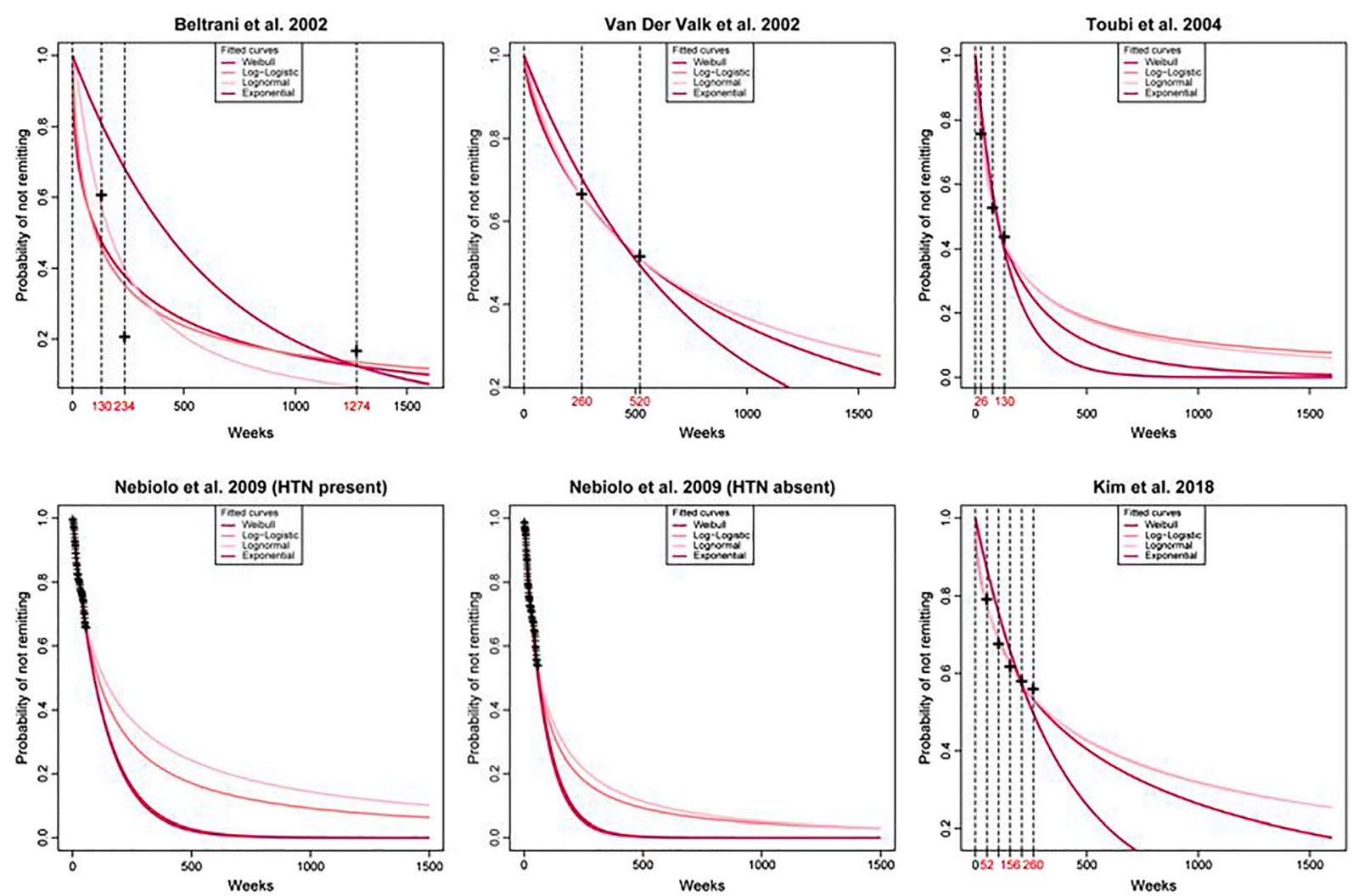

Fig. 1 Curve-fit using different distributions on data points from studies included in this review

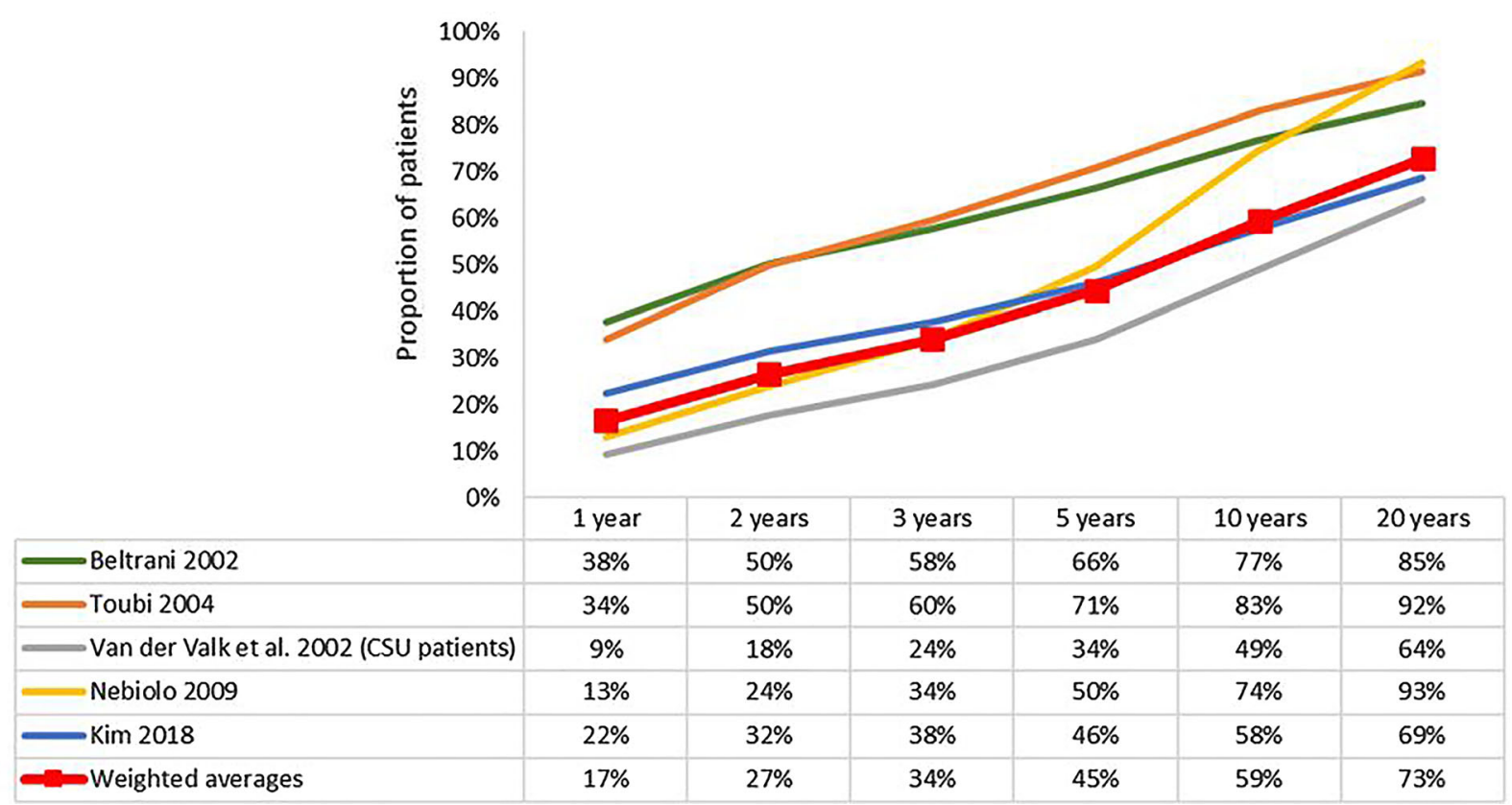

Fig. 2 Summary of cumulative remissions over year 1, 2, 3, 5, 10 and 20 (based on estimated 4-weekly remission rates) 
3 months while patients were not undergoing therapy" [9], while another study reported the proportion of patients "completely" or "fully cleared" of CSU based on a self-assessed patient questionnaire of disease symptoms [10]; however, the operational definition of remission was unclear in this latter study. Thus, there is a need to standardize the definition of remission applied in studies of CSU and provide clear descriptions of the target population profile and time points. A better understanding of typical times to natural remission allows planning for allocation of resources, especially when drugs do not appear to influence duration of the condition.

\section{Limitations and Contributions}

This literature review has a number of limitations. The evolving understanding of urticaria in recent years has led to changes in the nomenclature and definitions of 'remission', which could have hindered data extraction and appraisal. The studies conducted in secondary care centers/centers of excellence were conducted among patients with more severe cases managed in these settings and therefore may not be representative of all CSU patients. A unique contribution of this study is its analytical approach to adapt the literature-based estimates of spontaneous remission rates. The analysis used the limited number of data points available for determining remission rates. While the method is an improvement over methods which assume a constant average rate over time, it is acknowledged that there are limitations to the approach and that the use of patient-level data may provide more robust estimates of remission rates. The estimate of remission rates obtained from the combined data across studies is based on the assumption that the populations studied across the multiple studies are homogenous. However, this might not be true as the 4-weekly remission rates demonstrated high variability and various definitions of remission were used. Furthermore, all of the studies that were used to estimate remission rates were conducted in specialized referral clinics or secondary/tertiary care settings, as opposed to primary care settings, which may bias the patient sample to those with more severe disease. As a result, the study findings may not be generalizable to the mild or general CSU patient population.

This review highlights the fact that some studies did not provide a clear profile of the study population or included heterogeneous populations with CSU and inducible urticaria. The international CSU treatment guidelines now provide clear definition of all forms of $\mathrm{CU}$, including CSU which is the preferred term to name this condition [4]. Future studies should take these guidelines into account. Many potentially relevant studies were excluded if they did not define the patient population as specifically having CSU, although attempts were made to include studies referring to CSU even if they referred to $\mathrm{CU}$ in general. For example, studies were included in the review if they referred to "CU with an unknown aetiology" that is indicative of CSU. Regarding treatment and its potential impact on remission rates, no assessment could be carried out as the role of treatment on remission rates was not reported. No study clearly excluded patients receiving treatment for CSU, or presented outcomes separately for patients receiving treatment compared to untreated patients. Such studies would have been of particular interest here as they could have provided the best evidence on rates of spontaneous natural remission of CSU, as opposed to absence of symptoms associated with effective treatment. However there is no evidence to date that treatments can influence the occurrence of natural remission in CSU.

\section{CONCLUSION}

The primary aim of this study was to synthesize CSU remission rates reported in the literature based on a review of existing published evidence. A secondary aim was to fit distributions to the extracted data in order to extrapolate and generate estimates of monthly remission rates in CSU. The review revealed that although data on spontaneous remission are available, there is an inconsistency in the reporting of such data 
across studies and variability in the definitions of spontaneous remission. These findings reinforce the need for standardizing the definition of symptom remission in CSU and uniform reporting of remission rate data to allow comparisons across studies in the future. The present analytical approach to extrapolate literature-based remission rates provides a robust technique. Due to the wide range of remission estimates in the literature, face validation via expert clinical opinion is recommended to determine appropriate estimates for use in future analyses. We suggest that any further studies define remission as the date from which no symptoms are present after withdrawal of all treatments, provided that remission is found to be completely sustained for at least 3 months thereafter.

\section{ACKNOWLEDGEMENTS}

Funding. This analysis and the journal's rapid service fee was funded by Novartis Pharmaceuticals UK Ltd and Novartis Pharma AG.

Authorship. All named authors meet the International Committee of Medical Journal Editors (ICMJE) criteria for authorship for this article, take responsibility for the integrity of the work as a whole, and have given their approval for this version to be published.

Author Contributions. All authors contributed to the study conception and design. Saoirse A. Leonard contributed to literature search. The draft manuscript was written by Manik Kalra and all authors commented on and critically revised subsequent drafts. The analysis to estimate remission rates was conducted by Gautam Partha.

Disclosures. Maria-Magdalena Balp, Anna Halliday, Thomas Severin, Gautam Partha, Manik Kalra are Novartis employees and have no further conflicts of interest to disclose.Saoirse A. Leonard is an employee of Costello Medical Ltd. and was contracted by Novartis to support the literature search which informs this manuscript.Alexander M. Marsland is a dermatologist and specializes in the area of urticaria. He contributed to this study as an external clinical expert. He has received consultancy fees/assistance with conferences/ speaker fees from: Almirall, Galderma, Novartis, UCB Pharma.

Compliance with Ethics Guidelines. This article is based on previously conducted studies and does not contain any new studies with human participants or animals performed by any of the authors.

Data Availability. Data sharing is not applicable to this article as no datasets were generated or analyzed during the current study.

Open Access. This article is licensed under a Creative Commons Attribution-NonCommercial 4.0 International License, which permits any non-commercial use, sharing, adaptation, distribution and reproduction in any medium or format, as long as you give appropriate credit to the original author(s) and the source, provide a link to the Creative Commons licence, and indicate if changes were made. The images or other third party material in this article are included in the article's Creative Commons licence, unless indicated otherwise in a credit line to the material. If material is not included in the article's Creative Commons licence and your intended use is not permitted by statutory regulation or exceeds the permitted use, you will need to obtain permission directly from the copyright holder. To view a copy of this licence, visit http://creativecommons.org/licenses/by$\mathrm{nc} / 4.0 /$.

\section{REFERENCES}

1. Zuberbier T, Aberer W, Asero R, et al. The EAACI/ $\mathrm{GA}^{2} \mathrm{LEN} / \mathrm{EDF} / \mathrm{WAO}$ guideline for the definition, classification, diagnosis, and management of urticaria: the 2013 revision and update. Allergy. 2014;69(7):868-87.

2. Staubach P, Eckhardt-Henn A, Dechene M, et al. Quality of life in patients with chronic urticaria is differentially impaired and determined by 
psychiatric comorbidity. $\mathrm{Br}$ J Dermatol. 2006;154(2):294-8.

3. Maurer M, Abuzakouk M, Berard F, et al. The burden of chronic spontaneous urticaria is substantial: real-world evidence from ASSURE-CSU. Allergy. 2017;72(12):2005-16.

4. Zuberbier T, Asero R, Bindslev-Jensen C, et al. The International EAACI/GA ${ }^{2} \mathrm{LEN} /$ EuroGuiDerm/ APAAACI guideline for the definition, classification, diagnosis and management of urticaria. Allergy. 2021. https://doi.org/10.1111/all.15090.

5. Maurer M, Magerl M, Metz M, Zuberbier T. Revisions to the international guidelines on the diagnosis and therapy of chronic urticaria. J Dtsch Dermatol Ges. 2013;11(10):971-7.

6. Beltrani VS. An overview of chronic urticaria. Clin Rev Allergy Immunol. 2002;23:147-69.

7. Kozel MM, Mekkes JR, Bossuyt PM, Bos JD. Natural course of physical and chronic urticaria and angioedema in 220 patients. J Am Acad Dermatol. 2001;45(3):387-91.

8. Kulthanan K, Jiamton S, Thumpimukvatana N, Pinkaew S. Chronic idiopathic urticaria: prevalence and clinical course. J Dermatol. 2007;34(5): 294-301.

9. Nebiolo F, Bergia R, Bommarito L, et al. Effect of arterial hypertension on chronic urticaria duration.
Ann Allergy Asthma Immunol. 2009;103(5): 407-10.

10. van der Valk PG, Moret G, Kiemeney LA. The natural history of chronic urticaria and angioedema in patients visiting a tertiary referral centre. Br J Dermatol. 2002;146(1):110-3.

11. Boonpiyathad T, Sangasapaviliya A. Autologous serum and plasma skin test to predict 2-year outcome in chronic spontaneous urticaria. Asia Pac Allergy. 2016;6(4):226-35.

12. Chuamanochan $M$, Kulthanan $K$, Tuchinda $P$, Chularojanamontri L, Nuchkull P. Clinical features of chronic urticaria in aging population. Asian Pac J Allergy Immunol. 2016;34(3):201-5.

13. Kim YS, Park SH, Han K, et al. Clinical course of chronic spontaneous urticaria in the Korean adult population. Allergy Asthma Immunol Res. 2018;10(1):83-7.

14. Toubi EKA, Avshovich N, Bamberger E, Sabo E. Clinical and laboratory parameters in predicting chronic urticaria duration: a prospective study of 139 patients. Allergy. 2004;59:869-73.

15. Rabelo-Filardi R, Daltro-Oliveira R, Campos RA. Parameters associated with chronic spontaneous urticaria duration and severity: a systematic review. Int Arch Allergy Immunol. 2013;161(3):197-204. 